\title{
Unplugging in Language Learning and Teaching
}

\section{Laptinova Yuliia}

\author{
Kharkiv I. P. Kotlyarevsky National University of Arts \\ ORCID iD
}

https://orcid.org/0000-0002-4175-0858

\begin{abstract}
This article explores the possible way to make English Language Learning and Teaching more efficient among university students. Viewing language as a skill to acquire not a subject to study, the paper suggests Teaching Unplugged as an approach that empowers learners with the skills they need to speak in the target language outside the classroom. The article analyses psychological learning theory, which explains how people might acquire knowledge and learn. It also reviews some main principles and benefits of Teaching Unplugged as well as some of the issues that serve as a disruption for teachers and students. The article outlines one technique that could be used to unplug the classroom.
\end{abstract}

Key words: Teaching Unplugged, language learners, speaking skills, constructivism, 'Dogme' moment.

\section{Introduction}

Nowadays the majority of English learners are very motivated and goal-oriented. They learn another language in order to be fully functional in our global society. Goal-oriented students are demanding, and this motivates teachers to do their best to meet the goals of all their students.

Reflecting on my teaching at the University, I have noticed that the over-dependency on external obstacles (like pre-set syllabus, fixed course book, pre-decided order and pace, pre-selected grammar items) as well as the overuse of language learning resources available to you at a click of a button serve as a distraction for the learning opportunities in the classroom. Language Teaching and Learning should be treated as a process of jointly constructing speaking skills out of the talk yet materials overload and restrictions prescribed by a course hinder real classroom communication. Therefore, it is timely to enrich classroom activities and procedures by relinquishing the course book in exchange for the content provided by spontaneous conversation that occurs naturally amongst teachers and learners. What if we untether the lesson i.e. make our lessons free from course books, externally set syllabus and restrictive materials. We advocate the adoption of Unplugged method ("Dogme") which welcomes teachers' willingness and authority to keep this complicated balancing act between curriculum regulation and curriculum freedom. Luke Meddings and Scott Thornbury coined the term "Unplugged" ("Dogme") having adapted the philosophy of the film movement to English Language Teaching. The idea was to encourage the Language Learning and Teaching without all the photocopies, visual aids, and other handouts what is seen as excesses in the classroom and to take teaching back to its essence: the communication between teachers and students "making the most of minimal means" [3]. In their article “Teaching Unplugged: Dogme in English Language Teaching” Luke Meddings and Scott Thornbury state the precepts that lay the foundations of the Dogme Approach and, thus, establish grounds to classroom activities and procedures [5]. An education writer Janelle Cox in her article "Classroom Management: Benefits of Being Unplugged" states a few unexpected classroom management benefits language learners will have from an unplugged classroom, as well as ideas for how to make it work [1]. Ken Lackman has developed a method for 
Teaching Unplugged, which he has named Conversation Activated Teaching (CAT), implementing the main features of Dogme [3]. Lisa Dold views Teaching Unplugged not as a methodology to follow but rather as a mindset, which can be adopted by teachers who take issue with the proliferation of published materials or feel overwhelmed with a plethora of coursebook supplements [2]. Sharmila Pixy Ferris and Hilary Wilder, Professors at William Paterson University provide techniques to help teaching and learning in an age where technology untethers instruction from the classroom, from semester seat-time, and from a single source of expertise [7].

This paper intends to highlight and explain the main principles and ideas that underpin Teaching Unplugged; discuss constructivism learning theory as a ground for Teaching Unplugged; define the teaching/learning context required for a successful implementation of Teaching Unplugged; expose one effective and motivational technique to unplug the class; take a look at benefits of being unplugged.

\section{The main principles of the Unplugged approach}

- $\quad$ Conversation as a mode of language learning.

The most prominent feature of Teaching Unplugged is that it puts conversation at the heart of language learning [6]. This statement infers that conversation is both the process and the product of language learning. This comes from the belief that conversation is not a product of learning, but necessary for learning to happen. Spontaneous conversations in class allows learners to come up with coherent ideas, and not isolated sentences that might not be relevant. A focus on conversation is believed to better prepare learners to use language in real life. They are more likely to produce utterances in the full context of a conversation than produce a series of pre-fabricated phrases or structures in isolation.

- $\quad$ Generating the emergent language.

Dogme considers language learning to be a process where language emerges rather than one where it is acquired. The emergent language is the language that the students produce as they are talking spontaneously in class. As language is stimulated rather than simulated, there is no need to follow a syllabus that is externally set. Hence, there is no right order in which grammar structures should be learnt. Any grammar that is the focus of instruction should emerge from the lesson content, not dictate it. It should be more memorable as it comes from students' desire to communicate. It's also possible to let them decide on a language point they would like to work on. Knowledge is, therefore, constructed, instead of being imposed or transmitted by the teacher.

- $\quad$ Diagnosing the language and dealing with it.

The teacher's task is to watch out for learning opportunities that may simply spring up during lessons. If you hear an interesting expression used by a student, call other students' attention to it. Lisa Dold views the teacher's role is to help learners engage with emergent language - that means the teacher should diagnose the language and lexical gaps to target in follow-up work, without having established grammatical or lexical items prior to the lesson [2]. The language that emerges from the teacher-student interaction becomes core language and it is dealt with in exactly the same way teachers have always dealt with language.

- $\quad$ Scaffolding the learning process. 
Scaffolding is a key feature of effective teaching, where the teacher continually adjusts the level of his or her help in response to the learner's level of performance [4]. A teacher or more experienced peer is able to provide the learner with scaffolding hints, prompts, drilling exercises and direct instruction to support the development of speaking skills.

\section{- Untethering from pre-set restrictions.}

Perhaps most of university teachers today are being plugged into one or another curriculum, pre-decided order and pace, pre-planned syllabus, pre-selected course book. Moreover, having direct access to lots of resources and social media platforms internationally, they have subjected themselves to published materials, photocopies, supplements, handouts and other embellishments. Every teacher should look critically at the activities in their course books and feel free to reject them, if necessary, in favour of more meaningful and quality time in class. Being unplugged from pre-set distractions fosters interaction in class and allows language to emerge out of the communicative needs, interests and desires of the learners in the room. Scott Thornbury has noticed "By reducing the amount of material that is imported into the classroom, the teacher frees the learning space for the kind of interactive, talkmediated learning opportunities that are so crucial for language development" [8].

\section{The psychological ground for teaching unplugged}

Constructivism learning theory as a paradigm for teaching and learning establishes grounds for Teaching Unplugged since it explains how mere conversation leads to students actually learning. Social constructivism was developed by Lev Vygotsky who suggested that: 1) learning is the process of constructing new skills and knowledge only through active engagement with the real-world problem solving. This constructivist view of learning considers the learner as an active agent in the process of knowledge acquisition; 2) learning is a social process of interaction with a more knowledgeable participant. Vygotsky argued that the most effective learning occurs when the 'experts' (teachers) help 'novices' or 'apprentices' to develop their proficiency and stretch their skills [9]. Teachers cannot simply transmit knowledge to students, but students need to actively construct knowledge in their own minds by observing teacher or more experienced peer who are slightly more advanced than they are [4]. Thus, social constructivism suggests that learning is largely a collaborative process, where the new skills are jointly constructed in activity with more capable peers.

\section{Implementation of the Unplugged Teaching}

Success and effectiveness in an Unplugged classroom hinge on:

1) the changes in attitude to language learning and teaching. Students should cultivate the sense of agency rather than seeing learning as the teacher's responsibility. Agency involves the initiative or self-regulation of the learner, the awareness of the responsibility of one's own actions on others. Unplugged Teaching emphasizes that learning only takes place if learners are active and decisive decision-makers involved in the process of knowledge acquisition;

2) the complicated balancing act between curriculum regulation and curriculum freedom. On the one hand, every university has a prescribed curriculum framework that provides all who teach the courses with 
instructional resources, such as lesson plans. On the other hand, education policies give teachers flexibility to teach in the ways they think best. That is typically left up to teachers to bring life and passion to sometimes unrealistic or boring curriculum.

Passive learners and teachers rigidly enforcing the plan they envisioned for the lesson are completely irrelevant with these types of learning.

\section{How to unplug the classroom.}

A teacher who wishes to unplug the classroom should create a few unplanned moments in the class so that real communicative needs and language emerge. A "Dogme" moment is a concept describing those moments in a class when you get students speak by selecting suitable stimuli for conversation. A stimulus could be any questions about their professional issues, any controversial topic you think will create discussion, a photo, a set of questions, or even building upon the small talk that is already in progress at the start of the lesson. Students are most engaged by content they have created themselves. Buzz group discussions, debates and vocabulary games all work well with these lessons. Dogme moments can be experienced during many types of activities, which can be done without resources and which engage the students in maintaining a "good vibe" i.e. harmonious informal chatting, which doesn't seem to be something the teacher has planned. Thus, to experience this state, one has to stay away from the attention-robbers common in a modern fast-paced life. A first step would be to turn off your smartphone when speaking.

\section{Benefits of being unplugged.}

There are two important reasons why unplugged teaching will benefit your students.

1) Unplugging makes students more social.

Consulting electronic devices as well as preaching a point-by-point lesson plan are distracting. We have already become too addicted to the dings of our phones. Holding students' attention, computers disconnect us from alive communication. When you unplug from technology in the classroom you are essentially forcing face-to-face interaction among the students. The more social interaction language learners have without using technology, the better for jointly constructing speaking skills.

2) Unplugging makes students use their minds and imagination. It is easy to just "Google" or search "Pinterest" for an idea, but if you don't have access to technology, then it forces you to use your critical thinking skills.

\section{Conclusions}

The article argues that Language Teaching and Learning should be seen as a way to further improve and refine students' speaking skills by thought-provoking conversation, rather than a way to gain language knowledge prescribed by a course-book. Thus, language teaching and learning should be unplugged (disconnected) from distracting, unrealistic or boring external obstacles (prescribed course book, pre-decided order and pace, pre-planned syllabus, any sort of pre-selected materials) which divert attention from real classroom communication. The article advocates the adoption of Unplugged Language Learning and Teaching 
approach, which seeks to overcome the limitations imposed on teachers in the workplace and welcomes the learner as an active agent involved in the process of co-constructing speaking skills through the 'dialogic' nature of learning. Unplugged Teaching is grounded in social constructivism (a Psychological Theory of Learning) based on the work of Lev Vygotsky who suggested that learners jointly construct skills through interaction with other people under the guidance of an educator or more competent peer.

Successful Unplugged Learning and Teaching takes place if there is an "unplugged" moment - a stimulus of some sort (a photo, a set of questions, a professional issue), which generates a "good chatting vibe". By establishing and maintaining face-to-face cooperative interaction unplugging forces students to use their imagination and critical thinking skills.

\section{References}

1. Cox J. Classroom Management: Benefits of Being Unplugged. TeachHUB.com. Available at: https://www.teachhub.com/classroom-management-benefits-unplugged-classroom.

2. Dold L. Dogme: A Teacher's View. IH Journal of Education and Development. Available at: http://ihjournal.com/dogme-a-teacher's-view-by-lisa-dold.

3. Lackman K. Cat: A framework for dogme. Methods and activities for more effective teaching with less preparation, Toronto. Available at: http://kenlackman.com/files/cathandoutfinal.pdf

4. McLeod S. A. What Is the zone of proximal development? Simply Psychology. Available at: https://www.simplypsychology.org/Zone-of-Proximal-Development.html

5. Meddings L., Thornbury S. Teaching Unplugged: Dogme in English Language Teaching. Delta Publishing, 2009.

6. Parry J. Teaching unplugged: the revitalization of ELT? Carleton University, Ottawa, Ontario. Available at: https://www.semanticscholar.org/paper/TEACHING-UNPLUGGED\%3A-THE-REVITALIZATION-OFELT-Parry/71e2ebf06a8b251cf25594450d80f9e9ca875157

7. Sharmila Pixy Ferris and Hilary Wilder. Unplugging the Classroom: Teaching with Technologies to Promote Students' Lifelong Learning. Cambridge, Massachusetts: Chandos Publishing.

8. Thornbury S. Speaking Unplugged: 30 Activities for One-to-One Classes. Available at: https://www.onlinetefltraining.com/wp-content/uploads/2013/11/SpeakingUnplugged-30Activities.pdf

9. Vygotsky L. S. Mind in Society: Development of Higher Psychological Processes. Revised ed. Edition. Harvard University Press. 